\title{
DIAGNOSTICS IN SYSTEM MANAGEMENT BY ECONOMIC SECURITY OF ENTERPRISE
}

\section{ДІАГНОСТИКА В СИСТЕМІ УПРАВЛІННЯ ЕКОНОМІЧНОЮ БЕЗПЕКОЮ ПІДПРИЕМСТВА}

\author{
Oksana Sudakova ${ }^{1}$ \\ Kseniia Lopatka ${ }^{2}$
}

DOI: https://doi.org/10.30525/978-9934-26-021-6-21

\begin{abstract}
In the conditions of economical crisis many enterprises have to survive even though they were successful and functional before. That is why a problem of economical security of enterprises becomes more and more urgent. Considering this, the problem of revising existed principles and ways of economic security management of the enterprise has appeared. Preventing negative influence of internal and external factors is possible by providing the immediate reaction on them and creating conditions for safe development using the effective economic security management of the enterprise. The new ways of economic security management of the enterprise must correspond to the new demands which unstable environment of enterprises requires. One of those demands is efficiency of administrative decisions that we can provide by using modern instruments of management such as diagnostics.

Subject of the research is the diagnosis of the mechanism of economic security management of the enterprise in unstable modern conditions.

Methods of the research. The following methods have been used: general scientific methods of system approach and system analysis to generalize and develop theoretical and organizational economic bases of economic security in the system of strategic management of the enterprise and to analyze the current state of economic security of enterprises; general scientific methods of system analysis and specification for the formation of strategic goals of economic security management of the enterprise.
\end{abstract}

${ }^{1}$ Candidate of Technical Sciences, Associate Professor,

Associate Professor at Department of Economics and Entrepreneurship,

Prydniprovs'ka State Academy of Civil Engineering and Architecture, Ukraine

${ }^{2}$ Postgraduate at Department of Economics and Entrepreneurship,

Prydniprovs'ka State Academy of Civil Engineering and Architecture, Ukraine 
Purpose of the research is to develop theoretical instructions and recommendations for diagnostics in the system of economic security management of the enterprise

Results of the research. The following mechanisms have been developed: a mechanism for diagnosing the level of economic security of the enterprise, based on a system of key indicators; the mechanism of selection the points of growth of the enterprise based on ideas of the theory of constraints; the mechanism of enterprise recovery from the crisis, based on the concept of value management; management system of economic security of the enterprise on the basis of the reproductive approach taking into account influence of economic contradictions.

Conclusion of the research. To increase the efficiency of management and ensure the required level of economic security, a mechanism for diagnosing the level of economic security of the enterprise, based on a system of key indicators, has been developed.

\section{1. Вступ}

В умовах пандемії, загострення економічної кризи, що поставили на межу виживання ряд підприсмств, які ще донедавна вважалися успішними й стабільно функціонуючими, питання про економічну безпеку набуло особливої актуальності. Підвищення агресивності зовнішнього й, частково, внутрішнього середовища призвело до виникнення нових загроз і посилення їх впливу на результативність діяльності підприємств. Запобігання негативному впливу комплексу зовнішніх і внутрішніх загроз можливо шляхом забезпечення своєчасної реакції на них і створення умов для безпечного розвитку через ефективне управління економічною безпекою в рамках загальної системи управління суб'єктом господарювання. Прийняття оптимальних рішень в області управління й забезпечення економічної безпеки підприємств потребує вирішення ряду питань, пов'язаних 3 урахуванням сучасних тенденцій налагодження та розширення стратегічної взаємодії підприємств із суб'єктами зовнішнього середовища для забезпечення реалізації власних стратегічних інтересів. У зв'язку з цим виникло завдання перегляду існуючих принципів і підходів до управління економічною безпекою та їх вдосконалення з урахуванням нових вимог, які висуває нестабільне зовнішнє середовище функціонування підприємств. 
Одними $з$ таких вимог є оперативність і результативність управлінських рішень, що можна забезпечити використовуючи сучасні інструменти управління, до яких відноситься і діагностика.

Дослідження вітчизняних та зарубіжних вчених показують, що для підприємства більш важливим $€$ не уникнення загрози взагалі, а вміння іiі вчасно і точно передбачити для того, щоб вжити необхідних заходів. Це стосується як підприємств, що знаходяться у кризовому стані, так і успішно працюючих підприємств. Тому необхідним є розробка теоретичних положень щодо діагностики рівня економічної безпеки в кризових умовах функціонування підприємств.

\section{2. Структура системи управління економічною безпекою підприємства}

В умовах цивілізованих формах досягнення ринку та утримання конкурентних позицій господарюючих суб'єктів - це постійний процес, ускладнення якого обумовлено, з одного боку, наявністю безлічі чинників ризику, здатних за умови активізації їх дії принести колосальні збитки або навіть знищити матеріальні і фінансові ресурси, а, 3 іншого - нездатністю інституційних структур в більшості випадків розробляти і реалізовувати антикризові програми, що істотно знижує дію цих чинників. Забезпечення стійкості підприємств обумовлює необхідність наявності і дієвості системи економічної розвідки, що надає регулярну інформацію про стан і динаміку кон’юнктури ринків основних засобів і збуту продукції, а також про конкурентів, партнерів, контрагентів, нові технології, законодавчі акти і ін.

Необхідно виділяти такі укрупнені складові об'єкту системи управління економічною безпекою на підприємстві: самостійність підприємства; стійкість підприємства; здібність до розвитку.

Самостійність забезпечується відсутністю стороннього втручання в систему управління підприємством.

Стійкість підприємства передбачає стабільність і безперебійність процесів, які протікають на підприємстві, його здатність витримувати негативну дію чинників зовнішнього і внутрішнього середовища.

Здатність підприємства до розвитку проявляється в адаптації підприємства до нестабільного і динамічного середовища діяльності і характерна для будь-якої нормально функціонуючої системи. Названі 
об'єкти системи управління економічною безпекою на підприємстві взаємозв'язані і взаємообумовлені, оскільки розвиток повинен бути контрольованим, щоб забезпечити самостійність і стійкість (стабільність) підприємства.

Функція служби безпеки підприємства - забезпечення вказаних складових. Головні задачі суб'єкта управління економічною безпекою полягають в забезпеченні:

- самостійності шляхом захисту системи управління підприємством від зовнішнього втручання;

- стійкості підприємства шляхом захисту протікаючих на підприємстві процесів від зовнішніх і внутрішніх ворожих дій;

- самостійного і стійкого розвитку підприємства за допомогою надання його керівництву максимально повної і достовірної інформації про чинники зовнішнього і внутрішнього середовища, зниження рівня інформованості інших учасників ринку шляхом охорони власних секретів і дезінформації.

На підприємстві, для вирішення вказаних задач, в рамках системи безпеки можуть бути створені підрозділи, яким делегується охорона, забезпечення режиму, економічна розвідка, економічна контррозвідка.

Необхідно виділити ті чинники, які визначають місце системи економічної безпеки в організаційній структурі підприємства. Це особливості його конкурентного положення, позиція, яку займають власники і керівництво підприємства, їх компетентність і досвід управління, особисті й ділові інтереси, ділові якості співробітників підрозділів економічної розвідки і контррозвідки.

Важливою умовою стабільності і адаптивної підприємства в ринковій економіці є не тільки глибоке розуміння загальних закономірностей розвитку соціально-економічної системи, але і наявність всього спектру новітньої інформації про те, що ж відбувається в займаному їм сегменті ринку.

Структурний підрозділ - підрозділ економічної розвідки підприємства, на який покладені задачі єдиного в рамках суб'єкта господарювання інформаційного центру. Функції цього підрозділу - обробка і аналіз інформації, що забезпечує ухвалення вищим керівництвом обгрунтованих рішень по найважливішим для інтересів підприємства питанням. 
Головне призначення служби економічної розвідки полягає в забезпеченні керівництва достовірною, об'єктивною і повною інформацією про наміри партнерів, суміжників, клієнтів і контрагентів, про сильні і слабкі сторони конкурентів; в зборі даних, що дозволяють робити вплив на позицію опонентів в ході ділових переговорів; в сповіщенні про можливе виникнення кризових ситуацій; в моніторингу і контролі виконання укладених договорів і досягнутих раніше угод.

Тепер можна сформулювати завдання розвідувальної діяльності в економічній сфері на рівні суб'єкта господарювання як невід'ємної складової системи забезпечення його економічної безпеки:

1. Максимально ефективної інформаційної роботи організація, що виключає дублювання структурними підрозділами підприємства функцій один одного.

2. Розробка впливу коротко- і довгострокових прогнозів навколишнього середовища на господарську діяльність підприємства. Розробка рекомендацій щодо локалізації і нейтралізації чинників ризику, що активізуються.

3. Забезпечення керівництва підприємства своєчасно надійною і всебічною інформацією про стан внутрішнього і зовнішнього середовища, що дозволяє ухвалювати попереджувальні рішення і робити відповідні дії: виявлення загроз і чинників ризику, які можуть торкнутися економічних інтересів підприємства і перешкодити його нормальному функціонуванню.

4. Локалізація несприятливих чинників і посилення сприятливих чинників впливу навколишнього середовища на господарську діяльність підприємства та управління ризиками.

Відповідно до цих завдань, дії підрозділів, що забезпечують економічну безпеку підприємства і здійснюють розвідувальну і контррозвідувальну діяльність, полягають в попереджувальному виявленні джерел зовнішніх і внутрішніх загроз безпеки, що максимально знижує невизначеність стратегічного ризику. Ця діяльність повинна забезпечувати керівництво суб' єкта господарювання інформацією про істинні наміри потенційних і дійсних партнерів, про сильні і слабкі сторони конкурентів, дозволяти впливати на позицію зацікавлених осіб в ході переговорного процесу, сигналізувати про можливе виникнення кризових ситуацій, контролювати хід реалізації і дотримання партнерами 
досягнутих раніше домовленостей, виявляти несанкціоновані канали просочування конфіденційної інформації про підприємство через обізнаність про нього партнерів, клієнтів і конкурентів.

Етапи робота підрозділу економічної контррозвідки служби безпеки суб'єкта господарювання включають: виявлення, попередження, припинення спроб інфільтрації і вербування агентури конкурентами, партнерами і кримінальними структурами, запобігання просочування конфіденційної інформації про діяльність підприємства з боку його співробітників, партнерів і клієнтів, профілактичну перевірку лояльності його співробітників, службове розслідування фактів фальсифікації і розкрадань, оперативне прикриття персоналу, будівель і об'єктів підприємства.

Таким чином, підрозділ контррозвідки повинен попереджати негативні процеси в колективі підприємства (трудові конфлікти з адміністрацією, загрози страйків, масові порушення громадського порядку, загострення міжнаціональних відносин і т. п.). Виявлення і усунення причин і умов таких кризових ситуацій повинне проводитися як спеціальними (які передбачають застосування адміністративних дисциплінарних методів), так і соціально-психологічними методами (які сприяють узгодженню інтересів конфліктуючих сторін).

Тому, джерела загрози економічної безпеки підприємства можна розділити на зовнішні (конкуренти, контрагенти, партнери) і внутрішні (персонал).

Але, деякі дії, що представляють загрозу економічної безпеки підприємства, можуть носити кримінальний характер (в т. ч. дії із сторони корумпованих представників державної влади). При виявленні здійсненого злочину або ознак підготовлюваного підрозділ економічної контррозвідки підприємства повинен здійснювати тісну взаємодію 3 органами внутрішніх справ, СБУ і прокуратури.

Держава також може виступати в якості особливо небажаного джерела економічної небезпеки. В цьому випадку інструментом управління даною загрозою є лобіювання інтересів компанії в державних органах влади. Показовий приклад історії компанії Microsoft. Вона, після низки антимонопольних процесів, зразу ж набрала достатньо значний штат професійних лобістів і виділила на цю мету величезні кошти. 
Для забезпечення функціонування служби економічної безпеки їй необхідні інформаційні, матеріально-технічні, фінансові і кадрові ресурси. Предметом іï діяльності є інформація, тому для успішного здійснення поставлених задач, в першу чергу, потрібні інформаційні ресурси - масиви вхідної інформації і програмне забезпечення для іiі збереження, обробки, аналізу і узагальнення.

Тому, основою формування інформаційної бази служби безпеки підприємства покликане стати створення єдиного інтегрованого банку даних, який акумулював би всю інформацію, що поступає в службу безпеки, як з відкритих, так і з конфіденційних джерел.

Визначимо, що інформаційно-аналітична робота служби безпеки підприємства за розрізненими даними з різних джерел дає можливість відстежити і оцінити кризову ситуацію до того, як вона стане надбанням загальної гласності, а також розробити оптимальну антикризову програму, що є важливим чинником конкурентної боротьби і дає підприємству прямий економічний ефект.

\section{3. Концепція побудови механізму управління економічною безпекою підприємства}

Сучасний інтерес держави до безпечної діяльності підприємств диктується, насамперед, необхідністю забезпечення його економічної незалежності й цілісності, а також підвищенням політичного, економічного й соціального статусу на міжнародній арені. У свою чергу, суб'єкти господарювання, прагнуть забезпечити власні інтереси, які проявляються в прагненні до збереження й збільшення капіталу, що в сучасних умовах конкурентної боротьби вимагає використання спеціального арсеналу інструментів (методів і засобів), що чутливо реагують на невизначеність зовнішнього середовища й пристосування до функціонування в цих економічних умовах внутрішньої організаційно-управлінської системи. Все це дозволяе сформулювати концепцію побудови механізму управління економічною безпекою підприємства.

Головні положення концепції організації економічної безпеки підприємства полягають у наступному.

1. Формування механізму економічної безпеки сучасного підприємства варто здійснювати виходячи із принципового його подання як динамічної системи, що постійно змінюється за характеристиками 
ресурсів, прагне розширити кордони стратегічної зони господарювання шляхом освоєння ресурсних полів у нових зонах стратегічних інтересів.

2. Вивчення для організаційно-управлінського механізму управління економічною безпекою діяльності підприємств процесів формування загроз (i контрзагроз) у процесі їх розвитку необхідно здійснювати на основі аналізу й оцінки інформації з використанням двосторонньої асиметричної моделі.

Ця концепція асиметричної моделі тісно пов'язана 3 визначенням ефективності (економічної доцільності) розширення ресурсного поля підприємства в процесі його розвитку. Якщо інформаційна асиметрія, що характеризує ступінь загроз, значна, то можуть знадобитися й значні витрати на розробку альтернативних варіантів запобігання загроз. Але при цьому, відповідно до положень теорії ризику, варто давати оцінку й упущеним можливостям.

3. Механізм управління економічною безпекою підприємства необхідно формувати на основі загальних принципів побудови механізму, визначаючи індивідуально для кожного підприємства його склад, структуру, функції й взаємозв'язки з іншими компонентами (елементами) структури підприємства.

Необхідно створювати механізм управління цією безпекою для організації захисту економічної безпеки підприємства, призначення якого полягає в розпізнаванні загроз, прогнозуванні наслідків їх peaлізації, визначенні методів локалізації й видачі відповідних сигналів у загальну систему управління для прийняття певних оперативних рішень або для коректування тактичних і стратегічних цілей та завдань.

4. Компонентами управління економічною безпекою підприємства повинні бути підсистемою системи стратегічного й оперативного управління підприємством.

Можлива успішна реалізація програми організації захисту підприємства тільки за умови системного й комплексного відстеження (моніторингу) об' єктивних і суб'єктивних факторів зовнішнього й внутрішнього середовища й своєчасного коректування стратегії й тактики в системі механізму управління його економічною безпекою.

Тактична складова компоненту управління економічної безпеки підприємства є вторинною, підпорядкованою в системі ієрархії управління 
по відношенню до організації стратегічної системи, а остання за ієрархією нижча стратегічної системи управління підприємства в цілому.

Взагалі, система захисту економічної безпеки підприємства припускає створення механізму протидії загрозам, що мають місце з боку як зовнішнього, так і внутрішнього середовища підприємства, який виникає як на об'єктивній, так і на суб'єктивній основі. У системі захисту, для прийняття рішень, необхідно створювати два напрямки: пасивне (вичікувальне або нейтральне), якщо загрози не містять у собі істотних мотивів, які можуть призвести до руйнування економічної системи підприємства, і активне (агресивно-наступальне), коли застосування до об'єкта інтересів загроз протилежними сторонами може істотно вплинути на займаний життєвий простір підприємства в зоні стратегічного господарювання або прогнозоване його розширення в зоні стратегічних інтересів. В цьому випадку доцільно використати рефлексивну або асиметричну інформацію, що спотворює справжні наміри активно діючої сторони, введення в оману конкурентів шляхом їхньої дезінформації.

У цій системі особливу увагу варто приділяти моніторингу поведінки макросередовища першого порядку, у контурах якого перебувають державні пріоритети політичного й економічного характеру, регульовані законами або іншими нормативно-правовими документами, а також комплексу форс-мажорних обставин. Які представлені в системі управління економічною безпекою як загрози об'єктивного характеру. На практиці найчастіше використовується метод адаптації як пасивна, вичікувальна складова захисту інтересів господарюючого суб'єкта. Але це не виключає введення в механізм організації захисту підприємства методу лобіювання його інтересів у відповідних державних інститутах.

5. Сукупність управлінських, економічних, організаційних, правових і мотиваційних способів захисту довгострокових інтересів підприємства варто розглядати як механізм організації економічної безпеки підприємства.

Правова складова, що забезпечує пріоритет ієрархічних інтересів державної й регіональної безпеки повинна бути головним компонентом цього механізму.

Власне організаційний механізм варто будувати як гетерогенну систему, що складається з різних, але відповідних одна одній, ресурс- 
них й організаційних підсистем. При цьому ресурсні підсистеми являють собою об'єкт захисту, а організаційні - окремі структурні підрозділи організації: відділи, групи фахівців, окремі фахівці, що виконують функціональні обов'язки постійного або довгострокового характеру, або тимчасові творчі колективи, які виконують функції короткочасного, оперативного характеру; а також методи, способи й інструменти, що використовуються для виконання окремих завдань.

Використання специфічних методів й інструментів захисту або стимулювання його розвитку вимагає кожний вид ресурсів. А тому й організацію економічної безпеки підприємства важливо розглядати не тільки як необхідний процес формування умов наступального (агресивного) характеру розвитку, тобто організації ефективної розвідки й залучення нових ресурсів, у тому числі матеріальних, нематеріальних, трудових, фінансових, але і як організацію захисту у формі адаптації або у формі узгодження інтересів конфліктуючих сторін. Можна погодитися 3 думкою вчених і практиків про те, що розвідка й захист є нероздільними сторонами процесу прогресивного забезпечення стійкості функціонування, тобто безперервності життєвого циклу підприємства.

6. Як і будь-якого механізму, формування механізму забезпечення економічної безпеки підприємства, базується на системі основних правил - принципів його організації.

Це такі принципи, як відомі принципи побудови різного роду організаційно-управлінських механізмів, так і ті, які відбивають специфіку формування механізму, що забезпечує прогресивний розвиток підприємства.

7. Повинне бути створено спеціалізованого функціонального підрозділу підприємства, як підсистеми його стратегічного управління для забезпечення ефективного управління системою економічної безпеки підприємства.

Рішення кожного завдання, що постають перед системою безпеки, вимагає вибору моделі організаційного проектування, тобто моделі прийняття управлінських рішень, що визначають структуру, процеси координації й контролю над ходом впровадження певних заходів щодо захисту інтересів підприємства.

8. Підтримка стійкого й максимально ефективного функціонування підприємства в даний час і нагромадження достатнього потенціалу для збалансованого розвитку й стабільного росту - у майбутньому має 
бути основою для забезпечення достатнього рівня економічної безпеки підприємства.

Виходячи із власних умов господарювання, підприємство повинне самостійно визначати точку стало безпечного стану, що характеризується збалансованістю загроз і протидії їм у рамках його життєвого простору.

9. Забезпечувати захищеність всіх комунікаційних каналів і транзакцій, пов'язаних з організацією, зберіганням, передачею, виробництвом і відтворенням інформаційних ресурсів підприємства і їхніх похідних на всіх рівнях управління підприємством повинна система управління економічною безпекою.

Процеси, пов'язані з організацією безпеки, розподіляються на процеси безпечного розвитку інформаційних властивостей і властивостей інформаційних ресурсів. При цьому визначається основна властивість, що є переважаючою для суб'єкта рівня управління підприємством. Об'єктивність, вірогідність, адекватність, своєчасність, коректність, точність і корисність розглядаються у якості початкових властивостей. 3 розвитком властивостей суб'єктами різних рівнів управління підприємством зв'язуються процеси розвитку. У відповідності зі стандартом економічної безпеки й посадовими повноваженнями (інструкціями) здійснюється практична реалізація безпечного розвитку підприємства.

10. Забезпечувати категорії інформаційної безпеки - конфіденційність, цілісність, доступність компонентів інформаційних ресурсів підприємства (баз даних, системного й прикладного програмного забезпечення, включаючи програмне забезпечення захисту інформаціiі) на всіх рівнях управління підприємством повинна система управління економічною безпекою підприємства.

До положень захищеності інформації й інформаційних систем відносяться дані категорії, що визначають властивості. Пропонується матрично - табличне подання, що дозволяє оцінити це відношення якісно або кількісно, або ж на рівні уявлення «відсутність/ наявність» для формального уявлення відносин інформаційних властивостей і процесів розвитку інформаційних ресурсів та категорій безпеки. Що дозволить оцінити економічну ефективність так званої мінімальної конфігурації профілю захисту інформаційної системи підприємства. 
11. Дію й різні форми прояву людського фактора й містити в собі елементи системи підтримки необхідного по відношенню до зовнішнього й внутрішнього середовища підприємства безпечного рівня інформаційно-психологічної й мотиваційної стійкості персоналу підприємства повинна враховувати система управління економічною безпекою підприємства.

\section{4. Принципи побудови механізму управління безпекою підприсмства}

Використання системи принципів, тобто справедливих за певних умов рекомендацій високого рівня узагальнення, що відбивають закономірності предмета 3 позицій дослідження їх різними прикладними науковими дисциплінами вимагає побудова організаційно-управлінського механізму забезпечення економічної безпеки підприємства.

До системи принципів можна віднести наступні:

1) узгодження зі стратегічними цілями розвитку підприємства поточних проблем, завдань і можливостей підприємства;

2) розглядання підприємства як динамічної системи, що розвивається шляхом розширення свого життєвого простору;

3) діагностування управління підприємством як системою, що постійно перебуває в суперечності із зовнішнім середовищем, а також має систему внутрішніх протиріч.

Принцип самовизначення - важливий принцип організації управління економічною безпекою підприємства. Який визначається як наслідок об'єктивної закономірності функціонування підприємства в ринковому середовищі, що під тиском незаперечних фактів і на основі об'єктивної оцінки сформованої ситуації може поставити його в умови відмови від руху до наміченої стратегічної мети. Тобто, може наступити така ситуація, при якій безпека знизиться до деякого критичного рівня «болючого порога», і тоді пріоритетними будуть інтереси більш високого порядку, наприклад, збереження підприємства як організації. Коли результати діагностики й оцінки сформованих обставин вказують на необхідність збереження матеріально-ресурсного й організаційного стану підприємства, переорієнтації його стратегічних намірів, реалізації системи реінжинірингу, можливий такий стан підприємства. 
В системі забезпечення економічної безпеки підприємства особливе місце займає принцип контролю, що передбачає здійснення постійного спостереження й оцінки відхилень від системи індикативних показників у формі організації їх діагностики. Він передбачає також здійснення постійного контролю й оцінки ефективного функціонування й самого механізму організації економічної безпеки підприємства з метою його постійної адаптації до змін зовнішніх та внутрішніх умов діяльності підприємства, тобто якісного перетворення.

\section{5. Формування механізму управління економічною безпекою підприємства}

Важливе місце у системі економічної безпеки, як елементі економічної системи підприємства в цілому, приділяється керуванню, під яким розуміється процес організації прямого і зворотного зв'язку між інформаційно-обліковою системою й системою, що приймає тактичні й стратегічні рішення.

Створення системи, що забезпечує, як мінімум, розпізнавання загроз, прогнозування їхніх наслідків, визначення методів локалізації й видачі сигналів у загальну систему управління, де або приймаються оперативні рішення по усуненню загроз, або коректуються стратегічні цілі підприємства припускає загальна концепція функціонування організаційно-управлінського механізму економічної безпеки підприємства.

Організація збору інформації про загрози для вироблення й впровадження тактичних і стратегічних управлінських рішень, адекватних ситуаціям, які складаються в кожний конкретний період - це мета функціонування організаційно-управлінського механізму економічної безпеки підприємства. Дія цього механізму є циклічним процесом. Наявність традиційних, повторюваних, так i, більшою мірою, виникнення нових ситуацій, часом слабко формалізованих, що мають місце тільки на підприємствах певних типів і характерних для певних відносин, сформованих у його внутрішньому середовищі й при взаємодії із суб'єктами зовнішнього оточення є характерною функціонування організаційно-управлінського механізму економічної безпеки підприємства.

Розпізнавання й класифікація загроз, розробка й реалізація таких управлінських рішень, які дозволяли б підприємству вирішити основні 
завдання організаційно-управлінського механізму економічної безпеки підприємства:

- протидіяти не планованій зміні обсягів необхідних ресурсів шляхом розробки системи превентивних заходів у формі контр загроз;

- забезпечувати захищеність якості й обсягів споживаних і вироблених ресурсів від дестабілізуючих загроз зовнішнього й внутрішнього середовища;

- забезпечувати безпечну реалізацію програмних завдань, спрямованих на передбачувану зміну (розширення або скорочення) окремих ресурсів підприємства.

Використовувати асиметричну модель аналізу й оцінки інформації про загрози, що вимагає створення двох видів стратегії повинен механізм управління економічною безпекою. Перший вид стратегії повинен мати сценарії для втримання й розширення життєвого простору підприємства, а другий - сценарії вивчення (розпізнавання) стратегій, формованих іншими суб'єктами ринкового простору, інтереси й дії яких можуть істотно звужувати його життєвий простір.

\section{6. Діагностика рівня економічної безпеки підприсмства}

Врахування впливу факторів внутрішнього і зовнішнього середовища на рівень економічної безпеки підприємства, на сьогоднішній день більшість науковців погоджуються з необхідністю, що підтверджується запропонованими ними підходами до діагностики рівня економічної безпеки підприємства.

Виділення стратегічних і тактичних заходів вимагає управління економічною безпекою підприємства як складним, динамічним, інерційним процесом. Узгодження механізмів і заходів тактичного і стратегічного рівнів управління економічною безпекою підприємства $\epsilon$ необхідною умовою забезпечення ефективності управління. Проводиться таке узгодження на підставі оцінки ефективності політики точок зростання, оцінки ступеня досягнення стратегічних цілей, де мірою виступає вартість підприємства, а також оцінка дієвості програми виведення підприємства 3 кризи. Зворотним зв'язком виступають результати аналізу ефективності. Таким чином зворотний зв'язк формує перелік задач управління для подальшої розробки заходів щодо виведення підприємства $з$ кризи. 
Тактика та стратегія управління економічною безпекою тісно взаємозв'язані між собою. Розробляються і впроваджуються заходи тактичного характеру, спрямовані на реалізацію стратегічних планів на підставі розробленої стратегії діяльності з забезпечення заданого рівня цільових показників функціонування підприємства, виробленої глобальної стратегії управління безпекою. Однак, у той же час, результати тактичного управління економічною безпекою $\epsilon$ сигналами для зміни стратегії управління, прийнятої на базі ключових показників, наприклад, вартості підприємства в попередньому періоді, результатів здійснення ним своєї фінансово-господарської діяльності.

Важливість процесу діагностики рівня економічної безпеки в кризових умовах функціонування підприємств визначається тим, що цей процес дозволяє своєчасно виявляти несприятливі тенденції і загрози економічній безпеці підприємства, що виникають як у внутрішньому, так і в зовнішньому середовищі. В свою чергу це дозволяє виявляти «слабкі місця» i, відповідно, забезпечувати оптимальний розподіл i ефективне використання ресурсів з точки зору управління економічною безпекою підприємства.

Поставлена перед підприємством ціль задає напрям і обумовлює постановку відповідних завдань його функціонування. Формується набір показників згідно з цільовими установками підприємства, які якнайповніше характеризують його діяльність, а також є найбільш значущими індикаторами економічної безпеки, тобто мають найбільшу значущість серед всіх чинників для кожного з компонентів економічної безпеки підприємства. Запропоновані набори індикаторів підлягають вимірюванню на підставі попередньо обраного методу і з обгрунтованою періодичністю. формують базу для їх подальшого аналізу отримані значення індикаторів економічної безпеки підприємства, а саме відстежування тенденції їх зміни, порівняння з еталонними величинами. На підставі діагностики змін індикаторів економічної безпеки визначається вплив рівня на його регулювання, а також на перегляд цілей діяльності, що спричиняє зміни у функціонуванні підприємства, а отже, зміни в значеннях показників його діяльності і перегляд ключових індикаторів економічної безпеки, у зв'язку з чим знову змінюється рівень економічної безпеки, і так далі. 
Аналіз компонентів системи економічної безпеки підприємства на наявність проблем забезпечує виявлення обмежень у функціонуванні підприємства і визначення їх місця розташування, що є основною для їх діагностики: ідентифікації початкової причини виникнення обмеження, виявлення загальної картини взаємозв'язку всіх обмежень та ïx впливу на ступінь досягнення мети системою, а також визначення чинників, які підтримують існування цих обмежень.

Виявлені обмеження, грунтуючись на положенні теорії обмежень про можливість «розшивання» вузьких місць, можуть розглядатися як потенційні точки зростання. В даному механізмі процес вибору точок зростання підкріплений побудовою моделі процесу “Як є” і моделі “Як має бути”. У першій моделі процесу “Як є” відбивається поточний стан з урахуванням наявних обмежень, візуалізуються проблеми і створюється цілісне уявлення про ситуацію на підприємстві. Друга модель відображає бажаний стан, якого можна досягти шляхом зняття цих обмежень, тобто при застосуванні до них політики точок зростання.

Коли моделі побудовані, після цього оцінюється ефективність моделі “Як $\epsilon$ " з погляду необхідності перетворення обмеження системи в точку зростання підприємства, тобто приймається рішення про найбільш доцільне використання обмеження. Буває обмеження обрано для перетворення в точку зростання, то для того, щоб це перетворення було ефективним, необхідно, по-перше, визначити можливість розширення вибраного вузького місця, по-друге, спрогнозувати період окупності витрат на здійснення цього процесу, по-третє, відстежити і оцінити позитивні і негативні ефекти, які спричинить це подія, по-четверте, виявити перешкоди реалізації прийнятого рішення, по-п'яте, змінити підходи до управління системними ресурсами, які не є обмеженнями.

Визачимо, що механізм вибору точок зростання забезпечує вибір проблемної області підприємства, найбільш сприятливої з погляду застосування ресурсів і потенціалу розвитку, приведення способу іii функціонування до такого, який на підставі нейтралізації визначаючих проблему обмежень забезпечує максимальний мультиплікативний ефект розвитку для всього підприємства.

Основною причиною виникнення кризи є недоліки в управлінні, результатом яких може стати банкрутство підприємства, незважаючи на різноманітність чинників, які сприяють настанню кризових 
ситуацій на підприємстві. Ефективним інструментом діагностування прихованої стадії кризи може служити оцінка вартості підприємства. Оскільки найбільш поширеним в умовах ринкової економіки $є$ підхід до управління підприємством, направлений на максимізацію його вартості, з'являється необхідність в оцінці зміни вартості підприємства, а також в реалізації у відповідь реакцій з метою завчасного прогнозування зміни його стану. Для управління вартістю підприємства підставоюможе також служити той факт, що в Україні в більшості випадків балансова вартість підприємств істотно перевищує їх ринкову вартість.

В данній роботі запропоновано механізм виведення підприємства 3 кризи з урахуванням цих фактів. Він дозволяє оцінити ефективність управління; скоригувати стратегію розвитку підприємства відповідно до умов зовнішнього і внутрішнього середовища функціонування, що змінилися; забезпечує шляхи виведення підприємства 3 кризи, засновані на збільшенні його вартості і реалізацію потенціалу його розвитку, що базується на застосуванні визначених точок зростання підприємства.

Застосування методів оцінки вартості для визначення стадії кризи, в якій перебуває підприємство передбачає реалізація запропонованого механізму. Відповідно для цього, на підставі первинних показників діяльності підприємства, формуються чинники оцінки вартості, які відповідно до обраного методу використовуються в процесі оцінки вартості підприємства. На підставі отриманого результату визначається фаза кризи підприємства. Після цього здійснюється діагностика причин кризової ситуації.

Діагностика причин виникнення кризи визначаються точки зростання, вибір яких забезпечує проведення аналізу існуючої стратегічної позиції підприємства, що веде до розробки програми виведення підприємства 3 кризи, яка потім реалізується на підприємстві. У процесі реалізації програми виводу з кризи відповідно змінюються показники діяльності підприємства, і вже ці «майбутні» показники використовуються для оцінки вартості.

У зв'язку з впровадженими змінами оцінюється значення вартості підприємства, а отже, і приналежність його до інтервалу, що визначає стадію кризи. На підставі такої повторної оцінки стадії кризи проводиться діагностика ефективності програми виводу з кризи. 
Підвищення рівня економічної безпеки підприємства і його підтримка можлива лише при функціонуванні діагностики системи управління економічною безпекою підприємства.

\section{7. Висновки}

1. Для підвищення ефективності управління і забезпечення необхідного рівня економічної безпеки для підтримки життєво важливих функцій підприємства і реалізації його потенціалу було розроблено теоретичні положеня щодо діагностики економічної безпеки підприємства в умовах нестабільного економічного середовища, які передбачають структуризацію та класифікацію процесів щодо забезпечення економічної безпеки та дозволяе визначити комплекс механізмів управління економічною безпекою підприємства.

2. Розроблений механізм діагностики рівня економічної безпеки підприємства, заснований на системі ключових показників, забезпечує можливість оперативного контролю, регулювання і коректування діяльності з управління економічною безпекою в нестабільних умовах.

\section{Список літератури:}

1. Судакова О.І., Формалюк В.Д., Черевко В.О. Методологічні аспекти організації ефективної інформаційної безпеки підприємства. Вісник ОНУ. Серія : Економіка. 2019. Том 24. Випуск 5(78). С. 71-75

2. Судакова О.І., Попова В.В., Медведовська Т.П., Мещеряков О.С. Діагностика в системі управління економічною безпекою підприємства. Глобальні та національні проблеми економіки. 2016. № 13. URL: http://global-national.in.ua/issue-13-2016

\section{References:}

1. Sudakova O.I., Formalyuk V.D., Cherevko V.O. (2019) Metodolohichni aspekty orhanizatsiyi efektyvnoyi informatsiynoyi bezpeky pidpryyemstva. [Methodological aspects of the organization of effective information security of the enterprise]. Visnyk ONU. Seriya: Ekonomika, vol. 24, no. 5(78), pp. 71-75.

2. Sudakova O.I., Popova V.V., Medvedovska T.P., Meshcheryakov O.S. (2016) Diahnostyka v systemi upravlinnya ekonomichnoyu bezpekoyu pidpryyemstva [Diagnostics in the management system of economic security of the enterprise]. Hlobalni ta natsionalni problemy ekonomiky, no. 13. Retrieved from: http://global-national.in.ua/issue-13-2016 (accessed 01 December 2020). 